\title{
Desentralisasi Pendidikan: Proses, Implikasi dan Pengaruhnya Terhadap Arah Pendidikan Nasional
}

\section{Nur Widiantoro}

Kasi Supervisi dan Evaluasi Bidang Mapenda Karmwil Depag Provinsi Kalimantan Tengah

Abstract: The impact of education decentralization is giving appreciation for differences in ability and local conditions and community diversity in this country. Paradigm changes the education system will require a transition period which requires that every actor and education providers to be proactive, critical and have the passion to want to change. Educational autonomy in the framework of regional autonomy is quite a dilemma consequences among schooling. On the one hand, schools should be independent in creating quality, on the other side of the school still has many shortcomings (support). However, in the era of educational autonomy, the school should be able to compete with other schools in terms of improving the quality of its graduates. Background of this problem, this paper tries to give an idea about the process, the implications, the influence of decentralization of education to the direction of national education and solving problems that arise from this policy.

Keywords: Education, Decentralization, Notional Education.

\section{Pendahuluan}

Pendidikan dijadikan pijakan konkrit dalam upaya membangun karakter bangsa (nation dharacter brilding). Sudah saatnya, konsep pendidikan modern dan terarah yang sesuai dengan situasi dan kondisi serta kebutuhan masyarakat diterapkan oleh pemerintah. Patut disayangkan, saat ini, bangsa Indonesia belum memiliki konsep ideologi pendidikan yang jelas. Konsep pendidikan yang ada saat ini hanyalah "mengadopsi" konsep-konsep pendidikan yang dianut dunia Barat yang sebagian besar tidak mencerminkan budaya bangsa sehingga hanya menghasilkan individu-individu yang konsumtif dan berpikiran liberal.

Dalam dunia pendidikan, aspek sosial sangat berkaitan dan memiliki hubungan yang kuat terhadap konsep dasar pendidikan. Aspek sosial inilah yang memberi kerangka budaya pendidikan tersebut bergerak dan berkembang dalam memindahkan budaya, memilih serta mengembangkannya. Sistem 
pendidikan seyogianya berakar dan bercermin pada nilai-nilai sosial yang ada dalam masyarakat sehingga konsep pendidikan tersebut bisa diterima oleh masyarakat. Pendidikan tidak akan berkembang tanpa peran aktif masyarakar sebagai individu yang menjadi objek dan pelaksana sistem pendidikan. Konsep pendidikan harus mampu menyentuh aspek sosial masyarakat agar terjadi interaksi positif antara individu sebagai pelaku dan objek dengan sistem pendidikan.

Tidak ada kegiatan bangsa yang lepas dari peran pendidikan. Dalam banyak hal, peran pendidikan sangat menentukan untuk dapat melakukan kegiatan yang bermutu. Setiap bangsa menjadikan pendidikan kegiatan utama dalam mengusahakan kemajuannya. Dengan mengusahakan kemajuan sekaligus dibangun kekuatan bangsa itu.

Sejak tahun 1999, dalam rangka desentralisasi penyelenggaraan pemerincahan negara, pendidikan termasuk wilayah penyelenggaraan pemerintah yang kewenangan pengelolaannya dilimpahkan kepada daerah melalui otonomi daerah. ${ }^{I}$ Salah satu hasil dari gelombang reformasi total adalah lahirnya dua Undang-undang (UU), yaitu mengenai otonomi dan perimbangan keuangan antara pemerintah pusat dan pemerintah daerah. ${ }^{2}$ Perkembangan otonomi daerah di Indonesia senantiasa menarik untuk diikuti. Diawali tumbangnya pemerintahan Orde Baru yang sentralistis, reformasi tata pemerintahan akhirnya melahirkan model desentralisasi yang paling masif di dunia. Pemerintah daerah pada waktu yang bersamaan langsung menerima sebelas kewenangan wajib yang harus dilaksanakan.

Hanya lima kewenangan yang diurusi pemerintah pusat, yaitu kewenangan bidang pertahanan dan keamanan, hukum dan peradilan, moneter, agama, dan hubungan luar negeri. Selebihnya, di luar sebelas kewenangan wajib dan lima kewenangan pernerintah pusat itu dibagi habis antara pemerintah provinsi dan pemerintah kabupaten/kota. Pada perkembangannya, di antara sebelas kewenangan wajib yang diserahkan pada pernerintah kabupaten/kota itu, beberapa ditarik kembali pemerintah pusat. Misalnya, kewenangan bidang pertanahan, industri, dan perdagangan serta sebagian kewenangan bidang keschatan dan pendidikan. Instrumen hukum penarikan kembali beberapa kewenangan tersebut bervariasi. Mulai UU sektoral, peraturan pemerintah (PP), hingga surat edaran menteri. 
Puncak penarikan beberapa kewenangan itu adalah revisi UU No. 22/1999 tentang Pemerintah Daerah dan UU No. 25/1999 tentang Perimbangan Keuangan Pusat-Daerah. Revisi tersebut kemudian melahirkan UU No. 33 tahun 2004 tentang Pemerintah Daerah dan UU No. 34 Tahun 2004 tentang Perimbangan Keuangan Pusat-Daerah. Isu-isu yang relevan perlu dikaji secara cermat untuk kepentingan penelitian, penetapan kebijakan dan pendarnpingan agar pelaksanaan otonomi daerah tidak lagi mengabaikan rasa keadilan rakyat di tingkat daerah. Selanjutnya, diharapkan dapat diwujudkan pemerintahan daerah yang demokratis, bernafaskan kerakyatan, dengan menjunjung tinggi nilai-nilai budaya setempat dalam mencapai "masyarakat warga" yang selanjutnya tidak akan mengganggu proses integrasi bangsa. Hasil pendidikan selama Orde Baru adalah manusia-manusia robot dan sekadar menjadi pengikut setia struktur kekuasaan. ${ }^{3}$

Meskipun ada yang berpendapat bahwa Nation State atau Negara-Bangsa berakhir eksistensinya dalam masa globalisasi sekarang ini, namun NegaraBangsa menjadi aktor utama dalam arena dunia. Untuk itu, peran nasionalisme tetap penting yang amat tergantung dari sikap warga bangsa itu. Melalui pendidikan, harus ditumbuhkan kondisi mental bangsa itu, khususnya semangat nasionalisme yang kuat. Namun, pembangunan manusia tidak hanya untuk kepentingan bangsa. Pembangunan manusia juga dan terutama untuk kepentingan manusia itu sendiri. Henry M. Levin dalam buku The Limits of Educational Reom menyatakan:

"The assertion that educational sector serves to reinforce the exiting social order should not be construed to mean that change does not take palace. To the contrary, a dynamic process of social change is constantly evident, but it is not attributable to deliberate educational policy. The purpose of this section is to comment briefly on the origins of change and their relationship to education. In carrying out this charge attempt to compare to the concept implicit in this approach with those implied by the champions of change through educational reform. ${ }^{4}$

Pernyataan di atas mengandung maksud penegasan bahwa sektor pendidikan berfungsi untuk memperkuat tatanan sosial yang ada tidak semestinya diarahkan agar berarti bahwa perubahan tidak terjadi. Sebaliknya, proses dinamis perubahan sosial selalu terbukti, namun ini tidak bisa dinisbatkan pada kebijakan pendidikan yang baik, sektor pendidikan dan segala kegiatannya didominasi 
oleh masyarakat pensponsor. Selama tidak ada kontradiksi antara masyarakat dan sekolah, segala usaha serius untuk reformasi sekolah akan gagal karena sekolah akan mengikuti induknya bukan sebailknya. Lebih lanjut, tidak akan mungkin menggunakan sekolah sebagai panggung bagi reformasi sosial karena operasinya akan selalu dibayangi operasi masyarakat tuan rumah. Sekolah harus dipandang fungsional dalam menaati aturan permainan yang ditetapkan oleh masyarakat yang lebih besar, dan analisis atas sektor pendidikan harus mempertimbangkan asas ini. Akibatnya, hanya apabila ada tuntutan untuk reformasi pendidikan.

Bidang pendidikan merupakan salah satu bidang yang dapat diurus oleh pemerintah daerah. Pada bidang ini, tidak serta-merta segala sesuatunya diurus oleh pemerintah daerah. Akan tetapi, dalam hal pengelolaan secara penuh segala sesuatunya dirancang secara bertahap seiring dengan kesiapan dan ketersediaan pemenuhan persyaratan yang dibutuhkan. Otonomi daerah membawa konsekuensi logis pada otonomi pendidikan di daerah, khususnya dalam hal reorientasi visi dan misi pendidikan. Menyadari pentingnya peningkatan kualitas pendidikan dan kenyataan yang ada, maka dalam rangka menyongsong otonomi pendidikan dalam kerangka otonomi daerah dibutuhkan serangkaian inovasi. Inovasi yang dimaksud, di antaranya berupa pengelolaan pendidikan berbasis sekolah, peran aktif masyarakat di bidang pendidikan, dan guru yang profesional dan siswa yang berkualitas. Berangkat dari ketentuan UU Sisdiknas, pemerintah daerah sebagai bagian dari sistem pendidikan penyelenggaraan Pemerintah Negara Kesatuan Republik Indonesia bertanggung jawab mengelola pendidikan yang bermutu sesuai dengan standar nasional yang digariskan oleh pemerintah pusat.

Pembicaraan mengenai otonomi daerah tidak bisa dilepaskan dari asas desentralisasi yang menjadi landasan bagi pernbentukan pemerintah daerah. Desentralisasi adalah prinsip pembelahan wilayah satu negara ke wilayah-wilayah yang lebih kecil. Di wilayah-wilayah itu dibentuk institusi politik dan institusi administrasi untuk melayani kebutuhan orang atau masyarakat di satu tempat. $\mathrm{Hal}$ ini penting dilakukan karena pemerintah melaksanakan tiga fungsi dasar: service, regulation, dan empowerment. Hal itu dimaksudkan dengan maksud mengantisipasi kebutuhan masyarakat secepat, sedekat, dan setepat mungkin. 
Setelah kebijakan desentralisasi pendidikan dilaksanakan, ternyata memiliki beberapa dampak bagi pemerintah daerah. Dampat yang ditimbulkan bias berdampak positif dan berdampak negatif.

\section{Desentralisasi Pendidikan sebagai Tuntutan Nyata Masya- rakat}

Reformasi total yang melanda negara Indonesia telah meminta perubahanperubahan yang mendasar di dalam segala aspek politik, ekonomi, dan pengembangan kebudayaan. ${ }^{6}$ Salah bentuk reformasi adalah tuntutan otonomi daerah. Hal ini disebabkan pengalaman empirik bangsa yang sepanjang sejarah ternyata dikendalikan terpusat. Pemerintahan sebagai salah satu aspek pengendali itu memang sudah berlaku tidak adil terhadap daerah. Akibatnya, ketika peluang itu jebol, tak ada wacana lain bagi daerah yang paling layak dikembangkan selain otonomi.

Dalam Pasal 7 UU No. 22 disebut kewenangan daerah mencakup kewenangan seluruh bidang pernerintahan, kecuali kewenangan dalam bidang politik luar negeri, pertahanan keamanan, peradilan, moneter dan fiskal, agama, serta kewenangan bidang lain. Sementara itu, pasal berikutnya menjelaskan, kewenangan bidang lain tersebut meliputi perencanaan nasional dan pengendalian pembangunan nasional secara makro, dana perimbangan keuangan, sistem administrasi negara dan lembaga perekonomian negara, pendayagunaan sumberdaya alam serta teknologi tinggi yang strategis, koservasi, dan standardisasi nasional.

\section{Permasalahan dalam Desentralisasi Pendidikan}

Meskipun desentralisasi pendidikan tidak mudah dilaksanakan, namun desentralisasi pendidikan memberikan efek terhadap kurikulum, efisiensi administrasi, pendapatan dan biaya pendidikan, serta pemerataan. ${ }^{7}$ Manfaat yang diperoleh daerah dari pelaksanaan otonomi daerah tentu tidak hanya dibatasi pada makin besarnya kekuasaan politik yang dimiliki pemerintah lokal dan makin besarnya pernbagian kekayaan negara untuk pemerintah lokal. Salah satu keuntungan yang harusnya diperoleh adalah perbaikan kualitas pendidikan dengan adanya otonomi pendidikan. Daerah bisa lebih berkonsentrasi mengem- 
bangkan berbagai keunggulan daerah untuk dirumuskan dalam kebijakan pendidikan. Sayangnya, wacana tentang otonomi pendidikan atau manfaat otonomi daerah dan implikasinya terhadap pengembangan pendidikan di daerah jarang sekali mendapat perhatian publik. A.Hanief Saha Ghofur dalam buku Manajemen Penjaminan Muitu Pengumaan Tinggi di Indonesia Suatu Analisis Kebijakan menyatakan bahwa masalah lain yang dihadapi adalah pilihan dilematis antara memprioritaskan perluasan partisipasi memasuki lembaga pendidikan, atau memperbaiki mutu pendidikan. Pemerintah lebih memprioritaskan perluasan partisipasi dan akomodasi daya campung pendidikan tanpa melupakan walaupun harus menomorduakan perbaikan mutu ${ }^{8}$

Pelaksanaan desentralisasi pendidikan atau disebut otonomi pendidikan masih belum sepenuhnya berjalan sesuai dengan yang diharapkan karena kekurangsiapan pranata sosial, politik dan ekonomi. Dengan otonomi, tampaknya tidak ada perbaikan anggaran pendidikan dan kesehatan. Hanya beberapa kabupaten yang secara serius menggratiskan biaya sekolah bagi warganya. ${ }^{9}$ Otonomi pendidikan akan memberi efek terhadap kurikulum, efisiensi administrasi, pendapatan dan biaya pendidikan serta pemerataannya. Ada 6 faktor yang menyebabkan pelaksanaan otonomi pendidikan belum jalan, yaitu: (1) Belum jelas aturan permainan tentang peran dan tata kerja di tingkat kabupaten dan kota; (2) Pengelolaan sektor publik termasuk pengelolaan pendidikan yang belum siap untuk dilaksankana secara otonom karena SDM yang terbatas serta fasilitas yang tidak memadai; (3) Dana pendidikan dan APBD belum memadai; (4) Kurangnya perhatian pemerintah maupun pemerintah daerah untuk lebih melibatkan masyarakat dalam pengelolaan pendidikan; (5) Otoritas pimpinan, dalam hal ini bupati dan walikota sebagai penguasa tunggal di daerah kurang memperhatikan dengan sungguh-sungguh kondisi pendidikan di daerahnya sehingga anggaran pendidikan belum menjadi prioritas utama; (6) Kondisi dan setiap daerah tidak memiliki kekuatan yang sama dalam penyelenggaraan pendidikan disebabkan perbedaan sarana, prasarana dan dana yang dimiliki. Hal ini mengakibatkan akan terjadinya kesenjangan antardaerah sehingga pemerintah perlu membuat aturan dalam penentuan standar mutu pendidikan nasional dengan memperhatikan kondisi perkembangan kemandirian masing-masing daerah. 
Banyak kalangan yang berpendapat bahwa sebenarnya penyerahan hak keotonomian dari pusat langsung ke tingkat kabupaten dan kota itu terlalu cepar. Peran propinsi menjadi sangar tidak signifikan. Namun demikian, dalam karangka UU yang mungkin dilakukan oleh para gubernur adalah mencoba mengkoordinasikan atau menjalankan fungsi kordinasi dan pengawasan sebab diamanatkan dalam UU No. 22. Sayangnya, para gubernur merasa bahwa kewenangan yang mengkoordinasi dan kewenangan mengawasi itu dianggap tidak cukup sehingga membiarkan saja bupati dan walikota melakukan kebijakannya sendiri-sendiri.

Upaya untuk meningkatkan kualitas pendidikan seiring dengan otonomi pendidikan sudah seharusnya dikembangkan secara terus-menerus dan berkesinambungan. Secara prinsip, paradigma baru yang ingin dibangun dan serangkaian pembahasan ini adalah: Pengeloaan Pendidikan Berbasis Sekolah. Pada kerangka otonomi pendidikan, sekolah merupakan pilar utama dan terdepan untuk mewujudkan tujuan pendidikan secara komprehensif. Lebih lanjut, Martin Carnoy dan Henry M.Levin dalam buku The Limits Of Educational Reform mengemukakan:

According to the "Correspondence Principle" educational reforms become probable when the exiting educational approach and the results are contradicted by changes in the functioning of work organizations. ${ }^{10}$

Pernyataan tersebut mengandung maksud bahwa menurut prinsip korespondensi, reformasi pendidikan berkemungkinan terjadi ketika pendekatan pendidikan yang ada dan hasilnya berkontradiksi akibat perubahan dalam pengfungsian organisasi kerja. Dalam hal ini, reformasi pendidikan mempresentasikan tanggapan sistern pendidikan terhadap kontradiksi yang telah muncul. Hal ini dapat diasumsikan bahwa dapat diketahui jenis kontradiksi yang mungkin muncul antara tuntutan organisasi kerja dengan pendekatan pendidikan yang ada, maka dapat diprediksi sifar dan jenis reformasi pendidikan yang akan muncul.

Ada beberapa kalangan pemerhati yang khawatir bahwa desentralisasi pendidikan akan menciptakan kesenjangan yang semakin dalam antara kelompok perserta didik yang kaya dengan kelompok peserdta didik yang miskin. Banyakjuga mengungkapkan kekhawatirannya bahwa desentralisasi pendidikan hanyalah memindahkan penyakit kronis pendidikan dari tingkat pusat ke daerah. 
Apapun yang terjadi desentralisasi pendidikan guna menumbuhkan sikap demokratis, namun desentralisasi pendidikan tidak akan ada artinya tanpa diikuti adanya usaha-usaha perbaikan pada banyak aspek.

Proses desentralisasi pendidikan adalah proses yang rumit. Faktor-faktor yang menyebabkan desentralisasi pendidikan tampak rumit adalah: (1) Desentralisasi pendidikan akan menciptakan suatu sistem pendidikan dengan kebijakan-kebijakan yang konkret; (2) Desentralisasi pendidikan juga harus mengelola sumberdaya dan pemanfaatannya; (3) Desentratisasi pendidikan juga harus melatih tenaga kependidikan dan tenaga pengelola tingkat lapangan yang profesional; (4) Desentralisasi pendidikan juga harus menyusun kurikulum yang tepat-guna; dan (5) Desentralisasi pendidikan juga mengelola sistem pendidikan yang didasarkan pada kebudayaan setempat.

Dalam kaitan itu, jenjang dan jenis pendidikan dikotak-kotakkan sehingga tampak satu sama lain tidaklah berhubungan. Pendidikan tinggi seolah-olah tidak berkaitan dengan pendidikan menengah. Demikian juga dengan pendidikan menengah tidak berhubungan dengan sebagian pendidikan dasar. Segmentasi jenis dan jenjang pendidikan ini tampaknya merupakan hasil dari sistem birokrasi dan sentratisasi pengelolaan pendidikan. Dengan demikian, pendidikan tampak terpisah dan eksklusif dari masyarakatnya, serta tidak mengabdi pada kebutuhan masyarakat dan daerah. Pada peraturan pemerintah, yaitu PP No. 28/1990 yang berlaku selama-rezim Suharto berkuasa, membatasi pemerintah daerah hanya pada pengelolaan kepengurusan sekolah dasar. Fakta ini memberikan implikasi pada suatu kecenderungan bahwa pendidikan menjadi tidak relevan dengan kebudayaan masyarakat di mana lembaga pendidikan itu berada.

\section{Dampak yang Ditimbulkan Otonomi Pendidikan dan Upaya Pemecahannya}

Desentralisasi pendidikan merupakan salah satu cara di masa "pendidikan otoriter" tidak lagi dianut. Era yang dimulai secara formal melalui produk kebijakan otonomi pendidikan perguruan tinggi, kebijakan desentralisasi pendidikan yang mengacu pada UU No. 22 Tahun 1999 dan No. 25 Tahun 1999 yang direvisi menjadi UU No. 32 Tahun 2004 dan No. 33 Tahun 2004. Dalam hal itu, dapat ditangkap prinsip-prinsip dan arah baru dalam pengelolaan 
Desentratisasi Pendidikan: Proses, Implikasi dan Pengaruhnya

sektor pendidikan dengan mengacu pada pembagian kewenangan antara pemerintah pusat dan pemerintah daerah (provinsi dan kabupaten/kota) serta perimbangan keuangan antara pusat dan daerah. Ditengah ketatnya birokrasi pendidikan yang mengakibatkan rendahnya kualitas pendidikan, ternyata telah menjadi bagian dari ketidakpuasan masyarakat. Hal ini mendorong pemerintah (legislatif dan eksekutif) mengambil kebijakan politik mencari jalan keluar yang rasional sebagai upaya pemecahan untuk memtong birokrasi yang kaku dan sentralistik melalui suatu aturan perundang-undangan. ${ }^{11}$

Implikasi otonomi daerah bagi sektor pendidikan sangat tergantung pada pernbagian kewewenangan di bidang pendidikan yang akan ditangani pemerintah pusat dan pemerintah daerah. Oleh karena itu, sebuah sistem pendidikan nasional yang disahkan melalui UU Sisdiknas. Beberapa muaran dalam kebijakan ini secara tidak langsung mencoba melakukan perbaikan mutu pendidikan. Untuk itulah, partisipasi orangtua, masyarakat, dan guru sangat penting untuk mereformasi pendidikan ini, selain memecahkan masalah finansial melalui langkahlangkah yang diformulasi pemerintah baik pusat maupun daerah.

Katarina Tomasevski dalam buku Pendidikan yang Terabaikan mngemukakan bahwa hak atas pendidikan melibatkan empat kunci: pemerintah sebagai penyedia dan/atau pembiaya sekolah publik, siswa sebagai pemegang hak atas pendidik dan pernegang tugas untuk mengikuti ketentuan-ketentuan wajib belajar, orangtua siswa yang merupakan pendidik pertama, dan pendidik profesional yaitu para guru. ${ }^{12}$

Berangkat dari ide otonomi pendidikan, muncul beberapa konsep sebagai solusi dalam menghadapi kendala dalam pelaksanaan otonomi pendidikan.

a. Meningkatkan manajemen pendidikan sekolah

Pada dasarnya, kualitas pendidikan dapat ditinjau dari segi proses dan produk. Pendidikan disebut berkualitas dari segi proses jika proses belajar-mengajar berlangsung secara efektif, dan peserta didik mengalami pembelajaran yang bermakna. Pendidikan disebut berkualitas dari segi produk jika mempunyai salah satu ciri-ciri sebagai berikut: 1) Peserta didik menunjukkan penguasaan yang tinggi terhadap tugas-tugas belajar (learning task) yang harus dikuasai dengan tujuan dan sasaran pendidikan, di antaranya hasil belajar akademik yang dinyatakan dalam prestasi belajar (kualitas internal); 2) Hasil pendidikan sesuai 
dengan kebutuhan peserta didik dalam kehidupan sehingga dengan belajar peserta didik, bukan hanya mengetahui sesuatu, tetapi dapat melakukan sesuatu yang fungsional dalam kehidupannya (learning and learning); dan 3) Hasil pendidikan sesuai atau relevan dengan tuntutan lingkungan khususnya dunia kerja.

Selain itu, untuk dapat meningkatkan otonomi manajemen sekolah yang mendukung peningkatan mutu pendidikan, pimpinan sekolah harus memiliki kemampuan untuk melibatkan partisipasi dan komitmen dan orangtua dan anggota masyarakat sekitar sekolah untuk merumuskan dan mewujudkan visi, misi dan program peningkatan mutu pendidikan secara bersama-sama. Salah satu tujuan UU No.20 Tahun 2003 adalah untuk memberdayakan masyarakat, menumbuhkan prakarsa dan kreativitas, meningkatkan peran serta masyarakat, termasuk dalam meningkatkan sumber dana dalam penyelenggaraan pendidikan.

b. Reformasi lembaga keuangan hubungan pusat-daerah

Perlu dilakukan penataan tentang hubungan keuangan antara pusat dan daerah menyangkut pengelolaan pendapatan (revenue) dan penggunaannya (expenditure) untuk kepentingan pengeluaran rutin maupun permbangunan daerah dalam rangka memberikan pelayanan publik yang berkualitas. Sumber keuangan diperoleh dari pendapatan asli daerah, dana perimbangan, pinjaman daerah dan lain-lain pendapatan yang sah. Hal itu dengan melakukan pemerataan agar dapat mendukung pelaksanaan kegiatan daerah, terutama pada daerah miskin. Bila dimungkinkan dilakukan subsidi silang antara daerah yang kaya kepada daerah yang miskin agar pemerataan pendidikan untuk mendapatkan kualitas sesuai dengan standar yang telah ditetapkan oleh pemerintah.

\section{c. Kemauan pemerintah daerah melakukan perubahan}

Pada era otonom, kualitas pendidikan sangat ditentukan oleh kebijakan pemerintah daerah. Bila pemerintah daerah memiliki political will yang baik dan kuat terhadap dunia pendidikan, maka ada peluang yang cukup luas bahwa pendidikan di daerahnya akan maju. Sebaiknya, kepala daerah yang tidak memiliki visi yang baik di bidang pendidikan dapat dipastikan daetah itu akan mengalami stagnasi menuju pemberdayaan masyarakat yang well educated dan 
tidak pernah mendapat momentum yang baik untuk berkerabang. Otonomi pendidikan harus mendapat dukungan DPRD.

d. Membangun pendidikan berbasis masyarakat

Kondisi sumber daya yang dimiliki setiap dacrah tidak merata untuk seluruh Indonesia. Untuk itu, pemerintah daerah dapat melibatkan tokoh-tokoh masyarakat, ilmuwan, pakar kampus maupun pakar yang dimiliki pernerintah daerah kota sebagai brain trust atau tbink-tank untuk turut membangun daerahnya. Lembaga pendidikan juga harus membuka diri lebih banyak mendengar opini publik, kinerjanya dan tentang tanggung jawabnya dalam turut serta memecahkan masalah yang dihadapi masyarakat.

e. Pengaturan kebijakan pendidikan antara pusat dan daerah

Pemerintah pusat tidak diperkenankan mencampuri urusan pendidikan daerah. Pemerintah pusat hanya diperbolehkan memberikan kebijakankebijakan bersifat nasional seperti aspek mutu dan pemerataan. Pemerintah pusat menetapkan standar mutu. Pemerintah pusat hanya berperan sebagai fasilitator dan katalisator, bukan regulator. Otonomi pengelolaan pendidikan berada pada tingkat sekolah seingga lembaga pemerintah harus memberi pelayanan dan mendukung proses pendidikan agar berjalan efektif dan efisien.

\section{Arah Kebijakan Pendidikan Nasional dalam Era Otonomi Daerah}

Tidak sesuainya antara komitmen, harapan, tekad dan realitas di lapangan menggambarkan bahwa betapa dunia pendidikan berada dalam situasi yang mengkhawatirkan. Kondisi di atas diperparah lagi dengan masih kurangnya sarana dan prasarana sekolah di berbagai wilayah, tidak seimbangnya rasio guru dan murid, rendahnya kualitas guru, tidak terarahnya muatan kurikulum jika dibandingkan dengan visi besar pendidikan, tidak terintegrasinya antara kebijakan yang satu dan yang lainnya, dan sederet daftar persoalan lainnya.

Peringkat education development index (HDI) atau indeks pembangunan pendidikan di Indonesia tahun 2008 masih berada di urutan ke-65 dari 128 negara, dan masuk kategori pencapaian sedang. Sementara itu, negara tetangga, seperti Brunei, masuk kategori negara dengan pencapaian tinggi. Dalam hal daya saing SDM, data yang dikeluarkan Glabal Competitiveness Report tahun 2008 , 
Indonesia berada di peringkat 55, jauh di bawah Singapura, Malaysia, Cina, dan Thailand. Singapura berada di peringkat ke- 5 sementara Malaysia di peringkar 21 di tahun 2008.

Mencermati beragam persoalan yang menghinggapi dunia pendidikan dan menghadapi era persaingan global yang semakin kompetitif dan terbuka, pemerintah perlu melakukan terobosan-terobosan kebijakan yang mendasar dan fundamental, yaitu: (1) Hal yang mendasar dan utama adalah membenahi semua regulasi pendidikan; (2) Jika selama ini muatan kurikulum yang dijejali ke peserta didik begitu padat, maka perlu diadakan perampingan; (3) Pemerintah harus mengubah model dan metode pembelajaran yang selama ini lebih banyak menghadirkan teori pada setiap materi pelajaran; (4) Program wajib belajar (Wajar) tidak hanya berhenti pada program Wajar 9 tahun, tetapi harus ditingkatkan minimal sampai 12 tahun, yaitu padajenjang SMA; (5) Pemerintah perlu melakukan terobosan kebijakan yang signifikan dalam hal akses bagi setiap warga negara untuk menikmatijenjang pendidikan tinggi secara lebih mudah; (6) Secara nyata mempersiapkan peserta didik dapat bersaing dalam era global, penggunaan bahasa asing (terutama bahasa Inggris) harus benar-benar teraplikasi dalam kegiatan belajar-mengajar peserta didik; dan (7) Muatan materi pendidikan karakter bangsa yang beberapa waktu lalu diluncurkan oleh Mendiknas harus mencakup pendidikan moral, tidak hanya bagi peserta didik, tetapi juga bagi guru dan penyelenggara pendidikan lainnya.

Jika para pengambil kebijakan pendidikan di negeri ini memiliki kesadaran, maka komitmen dan tekad yang kuat untuk memajukan anak bangsa sudah mengubah paradigma dan kebijakan. Seharusnya bangsa ini tidak lagi menempatkan kebijakan pendidikan sebagai etalase eksklusif yang hanya bisa dilihat, tidak hanya menjadi komoditas politik berlabel pendidikan gratis yang hanya berwujud pencitraan ke publik, tetapi harus benar-benar hadir di tengahtengah masyarakat, dan dirasakan manfaatnya bagi kemajuan bangsa.

\section{Penutup}

Desentralisasi pendidikan memberikan apresiasi terhadap perbedaan kemampuan dan keberanekaragaman kondisi daerah dan rakyatnya. Perubahan paradigma sistem pendidikan membutuhkan masa transisi. Reformasi 
pendidikan merupakan realitas yang harus dilaksanakan sehingga diharapkan para pelaku maupun penyelenggara pendidikan harus proaktif, kritis, dan mau berubah. Belajar dari pengalaman sebelumnya yang sentralistik dan kurang demokratis, membuat bangsa ini menjadi terpuruk. Otonomi pendidikan pada kerangka otonomi daerah membawa konsekunsi yang cukup dilematis di kalangan persekolahan. Pada satu sisi, sekolah harus mandiri dalam mewujudkan kualitasnya, pada sisi lain sekolah masih banyak memiliki kekurangan (pendukung). Namun demikian, pada era otonomi pendidikan, sekolah harus mampu berkompetisi dengan sekolah lain dalam hal peningkatan kualitas lulusannya.

"Paradigma baru" otonomi pendidikan yang harus diemban dan diwujudkan oleh sekolah, melalui: (1) pengelolaan pendidikan berbasis sekolah; (2) peran serta aktif masyarakat di bidang pendidikan; dan (3) guru yang profesional dan siswa yang berkualitas. Ketiga hal itu hanya akan terwujud jika selunuh perangkar sekolah mampu menyadari dan melaksanakan tanggung jawab mereka secara optimal dalam bentuk sinergi kerja yang saling menunjang satu sama lainnya. Tanpa semua itu, otonomi pendidikan benar-benar hanya sebuah utopia.

Berkaitan dengan masalah pendanaan pendidikan, mestinya pemerintah pusat maupun pemerintah daerah tetap memiliki kewajiban menanggung biaya pendidikan pada lembaga dan satuan pendidikan yang didirikan oleh pemerintah maupun masyarakat. Pendanaan pendidikan yang mesti ditanggung pemerintah mencakup biaya operasional, biaya investasi, beasiswa, dan bantuan biaya pendidikan bagi peserta didik, berdasarkan standar pelayanan minimal untuk mencapai standar nasional pendidikan. Pembaharuan pendidikan nasional harus didasarkan pada paradigma peranan pendidikan dalam pembangunan nasional yang tepat, sesuai dengan realitas masyarakat dan kultur bangsa sendiri. Paradigma peranan pendidikan dalam pembangunan tidak bersifat linier dan unidimensional, melainkan peranan pendidikan dalam pernbangunan sangat kompleks dan bersifat interaksional dengan kekuatan-kekuatan pembangunan yang lain. 


\section{Endnotes}

1 Soedijarto, Landasan dan Arah Pendidikan Nosional Kita (Jakarta: Penerbit Buku Kompas, 2008), haL. 289. 85.

" H.A.R.Tilaar, Paradigma Baru Pendidikan Nasional (Jakarta: Rineka Cipta, 2004), hal.

1 Ibid., hal. 85.

${ }^{2}$ Martin Carnoy dan Hanry M. Levin, The Limits of Educational Reform (New York: David McKay Compamy,INC. 1976), haL. 38.

3 Soedijarto. Landasan..., hal. 291.

"Ibid., hal. 86.

'Ibid., hal. 87.

6 A. Hanjef Saha Ghofur, Manajemen Penjaminan Mutu Perguruan Tinggi di Indonesia Suatu Analisis Kebjjakan (Jakarta: Bumi Aksara. 2008), haL. 2.

Wahyudi Kusmorotomo dan Agus Pramusinto, Govemance Reformasi di Indonesia: Mencari Arah Kelembagaan Politik yang Demokratis dan Birokrasi yang Profesionol (Yogyakarta: Gava Media, 2009).

a Martin Carnoy dan Hanry M. Levin, The Limits..., haL. 83.

?.Syaiful Sagala, Desain Organisasi Pendidikan Dalam Implementasi Kebijakan Otonomi Pendidikan (Jakarta: Uhamka, T), hal. 27.

to Katarina Tomasevski, Pendidikan Yang Terabaikan: Mosaloh dan Penyelesaiannya (Jakarta: Dep.Huk \& Ham), haL 55.

\section{Daftar Pustaka}

Carnoy, Martin dan Hanry M. Levin. 1976. The Limits of Educational Reform, New York: David McKay Company, Inc.

Chourmain, Imam. 2008. Acuan Normatif Penelitian Untuk Penulisan Skripsi Tesis \& Disertasi. Jakarta: Al-Harmain Publishing House.

Dewey John. 1964. Democracy And Education. New York: The McMillan Company. Ghofur, A. Hanief Saha.2008. Manajemen Penjaminan Mutu Perguruan Tinggi di Indonesia Suatu Analisis Kebijakan. Jakarta: Bumi Aksara.

Sagala Syaiful. T. Desain Organisasi Pendidikan Dalam Implementasi Kebijakan Otonomi Pendidikan. Jakarta: Uhamka.

Soedijarto. 2008. Landasan dan Arah Pendidikan Nasional Kita, Wajib Belajar dan Peran Negara Empat Pilar Arah Kurikulum, Ujian Nsional Profesionalitas Guru, Anggaran Pendidikan, Akreditasi Nasioan. Jakarta: PT.Kompas Media Nusantara. Tilaar, H.A.R 2004a. Manajemen Pendidikan Nasional. Bandung: Rosdakarya 
Desentralisasi Pendidikan: Proses, Implikasi dan Pengaruhnya Cipta. 2004b. Paradigma Baru Pendidikan Nasional Jakarta: Rineka

Tomasevski. 2004. Pendidikan yang Terabaikan, Masalah dan Penyelesainnya, Jakarta: Departemen Hukum dan HAM.

Wahyudi, Kusmorotomo dan Agus Pramusinto. 2009. Governance Reform di Indonesia: Mencari Arah Kelembagaan Politik yang Demokratis Dan Birokrasi Yang Profesional. Yogyakarta: Gava Media. 